\title{
LIQUIDITY MANAGEMENT: IMPLICATIONS FOR FINANCIAL PERFORMANCE OF DEPOSIT MONEY BANKS (DMBS) IN NIGERIA
}

\section{(iD) Okere Wisdom ${ }^{1+}$ \\ Okeke Obiajulu \\ Chibuzo $^{2}$ \\ Echeonwu Sandra \\ Ijeoma $^{3}$ \\ (iD) Emili Eze \\ Celestine $^{4}$ \\ Rufai Oluwatobi ${ }^{5}$}

\section{Article History}

Received: 8 February 2021 Revised: 10 March 2021 Accepted: 14 April 2021 Published: 18 May 2021

\section{Keywords}

Liquidity

Performance

Profitability

Treasury single account.

\author{
${ }^{1,4}$ Department of Economics, Accounting and Finance, Bells University of \\ Technology, Ota, Nigeria. \\ ${ }^{2}$ Email: wisescar@yahoo.com Tel:+2347039889731 \\ 'Email:celestineemili@gmail.com Tel: +2348076116744 \\ ${ }^{2,9,5}$ Department of Accounting, Alex Ekwueme Federal University, Ndufu Alike, \\ Nigeria. \\ sEmail:ajuluokeke@yahoo.com Tel:+2348025116397 \\ 'Email:sandraecheonwu@gmail.com Tel: +2348111946573 \\ ${ }^{5}$ Email:tobi.rufai.tr@gmail.com
}

\begin{abstract}
This research assessed the impact of liquidity management on the financial performance of quoted deposit money banks in Nigeria. Secondary data were gathered from the corporate annual reports and accounts of fifteen (15) Banks for eleven (11) years spanning from 2007 to 2017. The agency theory was the theoretical framework upon which this study was hinged. Both descriptive and inferential statistics were adopted as analytical tools for the data. The results indicate that there exists a significant association amid liquidity management and financial performance of Deposit Money Banks in Nigeria. In addition, there exists a significant difference in the profitability of the Deposit Money Banks before and after the adoption of Treasury Single Account (TSA) in Nigeria. The study recommends that Deposit Money Banks should employ good liquidity management to mechanisms for a good performance and the Deposit Money Banks should reorganize its internal financial system in order to adapt to changes within the new policy (TSA).
\end{abstract}

Contribution/ Originality: This study contributes to literature by providing a more recent research findings in the field of liquidity management and Treasury Single Account discuss. Adopting the panel methodology, a robust analysis and findings have been presented and interpreted.

\section{INTRODUCTION}

The role of the banking sector in Nigeria cannot be overemphasized. Money serves as the resource that sustains the modern-day economy, money flows through the banking sector to various parts of the economy. If there is a problem with the banking sector; the economy is affected. Therefore, any policy that affects the banking sector may directly or indirectly affect the entire economy (Eugene, 2017). It is proven that countries that possess efficient banking system tend to develop and grow rapidly, than otherwise (Aurangzeb, 2012). The banking sector represents the heartbeat of an economy and its profitability is subject to different factors, of which liquidity is a major factor (Olarewaju \& Adeyemi, 2015). This sector is one of the major pillars of the nation's economy serving as a hub bringing together different businesses of all sizes, nature, industries and sectors of Nigeria, both privately and publicly owned, local and foreign, through the variety of services it offers. 
The banking sector has and continues to have positive impact on the Nigerian economy in various ways. These include provision of employment opportunities, provision of financial services, consultancy services, acting as centralized financial hub that links all enterprises and corporations together, serving as major link between foreign investors and the economy, being one of the major institutions that make international trade possible. In most developed and developing countries, the sector is regarded as the most important of all other sectors (Olarewaju \& Adeyemi, 2015).

A major determinant of a bank's liquidity is the ability to meet the demand deposit cash flow. Profitability and liquidity management are part of the most crucial parts of the business, which provide accurate view of any business operations. In the long-run, profitability and liquidity management are parallel to each other for strong work and promotion. Businesses are presumed going concerns in nature; hence profitability in the long run is expected in order to ensure their survival (Egbide, Uwuigbe, \& Uwuigbe, 2013). The liquidity of Deposit Money Banks shows its ability to fund its activities at the expected period of maturity, which covers lending, investment obligations, withdrawals, deposits as well as accrued liabilities (Amengor, 2010).

Liquidity Management according to Alshatti (2015) can be categorized into two: First, by the ability of a business to trade an asset, such as stocks and bonds with its current prices, Second, as large firms for instance financial institutions. Deposit Money Banks are usually assessed based on their liquidity and capacity to cover cash as well as collateral requirements without sustaining substantial losses. Therefore, in both cases, liquidity management entails all actions undergone by both investors and managers to decrease liquidity risk exposure. There have been a number of liquidity management corporate strategies which have been adopted in the banking sector. These strategies could be developed by either monetary or regulatory bodies, or by the bank itself in an attempt to meet matured obligations, maximize profit opportunities in the market or secure current public confidence (Duruechi, Ojiegbe, \& Otiwu, 2016).

As stated above by Eugene (2017) the banking sector is directly affected by the regulatory bodies which formulate polices for their operations. These polices could positively or negatively affect the operations of the banks. One of such policies is a recent public accounting policy known as treasury single account introduced in Nigeria in 2012 and fully implemented in 2015. This policy was introduced to consolidate the receipts, income and revenues of the government into a single account controlled by the government and any transactions performed by the government through the DMBs can only be done through the treasury single accounts held by the banks (Oyedele, 2015). The introduction of this policy was to promote the transparency and accountability of public funds. However, it may have impacted negatively on the liquidity of the DMBs.

Considering the nature and implementation of the TSA policy so far, it has prevented the DMBs from using the government deposited funds in its investment and other revenue generating activities, the cash inflow from these activities dropped, which adversely affected the liquidity of the banks and ultimately their financial performance. According to Sewa (2015) as cited in Obinna (2015) The CBN responded by dropping the minimum capital requirement from $31 \%$ to $25 \%$ in 2015 in a bid to compensate for the loss of liquidity, thereby improving liquidity management thereby attracting more private deposits. Yet, even with this arrangement by the Central Bank of Nigeria, the banking sector by virtue of the introduction of TSA has been put into a new form of liquidity crises.

The introduction of TSA negatively affected the volume and flow of liquidity of DMBs, as a result of the inability to invest the public funds deposited with them. It was estimated that the DMBs are losing about N2 trillion deposits to the $\mathrm{CBN}$ due to this policy. The study on liquidity management and financial performance in the banking industry is not new, but previous studies have produced inconsistent results. There are studies such as Ogundipe, Idowu, and Ogundipe (2012); Agbada and Osuji (2013); Ahmad (2016); Edem (2017) who discovered positive relationship between liquidity management and financial performance while that of Akter and Mahmud (2014); Molefe and Muzindutsi (2016) the existence of such relationship was denied. 
Hence, there are inconsistencies in past related literatures, which indicate the need for further research on the association amid liquidity management and financial performance especially that of Deposit Money Banks in Nigeria.

\section{LITERATURE REVIEW}

\subsection{Liquidity and Liquidity Management}

Liquidity refers to the amount of equity's capital, which can be used to meet short-term obligations. According to Biety (1998) liquidity is the speed and ease an asset can be sold and still realize fair price, although liquidity is centered on short term obligations it should not be neglected because the optimal capital structure of an entity is attained by factoring in both short term as well as long-term requirements of finance. This refers to the measure of the ability and ease of an entity to covert asset to cash, it describes the extent to which a marketable commodity or security may be purchased or sold without affecting its price. Liquid assets are assets which are simply transformed to cash when needed to meet financial obligation. In the case of banks, liquid assets may include: cash, bank reserve, government debts etc. Bank liquidity in general refers to the ability of banks to have the resources to meet its maturing obligations. It talks about the how banks see to cash, cheque and other withdrawal obligations and floating new loans on demand add still abide with the current reserve requirements.

Liquidity Management is the summation of all the activities, policies as well as measures put in place to ensure the entity is liquid enough to meet its short-term obligations and reduce its exposure to liquidity risks. These management measures could be CBN reserve requirement to DMBs, cash balances due to other deposit money banks (Duruechi et al., 2016). It provides the tools to minimize the tied down working capital, optimally manage liquidity risks and intra-group positions and enhance the value of liquidity pools on local or foreign currencies and at the same time, sustaining a real time visibility as well as control over cash flows of the entity. Liquidity management in banks involve the efficient as well as effective planning and organization of the bank's total assets which will improve its liquidity and profitability at the lowest cost. Davronov (2016) stated that liquidity management are the mechanisms employed to maintain the efficiency and stability of DMBs and the banking system as well.

\subsection{Financial Performance}

Financial performance is a measure of the results of the entity's policies and operations in monetary terms. It is a measure of how well the entities use its assets from primary mode of business and generate revenues. In this study, financial performance is measured with the use of profitability. According to Aburime (2008) profit refers to the excess of the turnover/revenue generated from sales/output over the full opportunity cost of the production factor of that output. Bank's profitability refers to the ability of a bank to generate revenue which will exceed its cost. Profitability is the ability of a company to use its resources to generate revenue in excess of its expense; basically it's the capability of a company to generate profit from its operations. It can be measured through profitability ratios such as return on asset (ROA), return on capital employed (ROCE) etc.

Profitability focuses on the level of turnover/ revenue to be generated to cover the cost of the entity's activities and still have a surplus (Ibe, 2013). He also stated that the profitability of an entity can be improved with the use of break-even analysis, marginal analysis, ratio analysis, cost and financial control; therefore, if a bank aims at improving its profitability then it must possess sufficient liquidity to transact and fund the business operations.

\subsection{Theoretical Framework}

The theoretical concept on which this research is based is Agency theory, which has its origin in the classic work of Berle and Means (1932) but has been modernized by Jensen and Meckling (1979). According to the principle, administrators working as agents for shareholders may have interests that clash with those of their 
principal. They (managers) are likely to follow desires that can benefit their principals because they (managers) are said to enjoy the perks of office and control even at the detriment of shareholder interests (the shareholders). Theoretically, based on the tradeoffs between liquidity control and firm results, there may be a positive, negative, or no statistical relationship. This study adopts the agency theory and is in line with other studies such as Bassey, Tobi, Bassey, and EKwere (2016).

\subsection{Empirical Review}

There are many authors who have examined the liquidity management and financial performance of deposit money banks both in Nigeria and abroad, also a few have studied it in relation to the adoption of TSA though it's still recent.

Duruechi et al. (2016) analyzed the effect of liquidity management measures on the performance of banks in Nigeria. Looking at the times series data for 25 years (1990-2014), the findings disclosed that the liquidity management measures have a positive effect on bank performance in Nigeria.

In Nigeria, Agbada and Osuji (2013) examined the effectiveness of liquidity management and banking efficiency. Their findings show that there is a clear correlation between liquidity management and bank efficiency, and that successful liquidity management can boost bank operations' soundness. This finding is in consonance with findings by Alshatti (2015) who examined the impact of liquidity management on profitability in Jordanian commercial banks, with the findings showing a positive effect on profitability when the fast ratio and allocation ratio of available funds are increased, and a negative effect on profitability when the capital ratio and liquid assets ratio are increased.

In another study by Ahmad (2016) on the relationship with liquidity management and profitability of Pakistan banks from a financial statement approach, using quantitative research designs, the study found out that there is a weak positive relationship between liquidity and profitability. The finding of Ahmad (2016) is in consonance with the study of Edem (2017) on Liquidity Management and Performance of Deposit Money Banks in Nigeria from 1986 - 2011. The results states that only the highly liquid banks can maximize their returns and illiquidity or excess liquidity can be threatening to the bank. Ndubuaku, Ohaegbu, and Nina (2017) also examined the impact of treasury single account on the performance of the banking sector in Nigeria. Their results indicate that the TSA had a significant impact on Credit to the Private Sector, Deposit Mobilization and Loans and Advances.

On the other hand, a study by Akter and Mahmud (2014) which examined the liquidity-profitability relationship in Bangladesh banking industry revealed that there was no significant relationship between the liquidity management and the profitability of the banking sector of Bangladesh.

Furthermore, the study of Andornimye (2017) on the impact of treasury single account implementation on bank liquidity in Nigeria revealed that TSA has a negative impact on the quick ratio of banks and a positive impact on the deposit mobilization by banks, also there was no significant relations to the creation of credit by banks to the public. Their study is consistent with the findings of Zayol, Iorlaha, and Nege (2017) who examined the effect of treasury single account on the liquidity of deposit money banks in Nigeria. Findings from the research revealed that the implementation of TSA will negatively affect the liquidity of DMBs in Nigeria. Ighosewe and Ofor (2017) also examined the effect of treasury single account on banks' performance in Nigeria. The results show a significant negative relationship between TSA and liquidity of banks and a positive significant relationship between TSA and job loss, also a negative significant relationship between TSA and the profitability of banks in Nigeria.

Based on the above findings from different researchers, the following hypotheses were formulated:

Hypothesis 1: There is no significant relationship between the liquidity management and profitability of DMBs of Nigeria.

Hypothesis 2: There is no significant difference in the liquidity of DMBs before and after the adoption of TSA in Nigeria. 


\section{METHODOLOGY}

The population of this study is fifteen (15) Deposit Money Banks listed on the floor of the Stock Exchange Market as at 2017 in Nigeria. The sample size of the study which is equal to the population of the study is the fifteen DMBs. For the purpose of this study, secondary data was used. The data was extracted from the annual reports and accounts of the selected banks; each report is within the timeframe of 2007-2017. This implies that there are a total of 165 observations in the study (11 years $\times 15$ listed DMBs in Nigeria). These financial statements are confirmed by the Securities and Exchange Commission's approval of the declaration, which is the single most reliable financial medium that has regularly issued financial reports of Nigerian companies for over 19 years with tight supervision (Okere, Isiaka, \& Ogunlowore, 2018).

\subsection{Model Specification}

This model captures the impact of liquidity management on the profitability of DMBs in Nigeria, using return on assets (ROA) as a proxy for profitability. This model was adapted from the model used in the work of Molefe and Muzindutsi (2016) which originally used:

$Y_{1 i t}=a_{0}+\alpha_{1} x_{1 i t}+\alpha_{2} x_{2 i t}+\mu_{1 i t}$

Where: $y_{i t}$ denote the profitability for bank i at time t, measured by ROA.

$x_{1 i t}$ Denote Capital ratio.

$x_{\text {2it }}$ Denote the Quick ratio.

$\alpha_{1}$ and $\alpha_{2}$ Denote the coefficients of the ROA equation.

$\alpha_{0}$ and $\alpha_{0}$ Serve as the respective constants for the ROA equation.

$\mu_{1}$ Serve as the respective error terms for the ROA equation.

For the purpose of this study, the model shall be:

$Y_{1 i t}=\alpha_{0}+\alpha_{1} x_{1 i t}+\alpha_{2} x_{2 i t}+\alpha_{3} x_{3 i t}+\mu_{i t}$

$x_{1 i t}:$ Investment ratio $=$ Net credit facilities $/$ Total deposits.

$x_{2 i t}:$ Current ratio.

$x_{\text {3it }}$ : Quick- Acid ratio.

$\mu=$ error term.

$\mathrm{Y}=$ Return on asset (ROA) for a bank $\mathrm{i}$ at a time $\mathrm{t}$.

Where $\alpha 1, \alpha 2, \alpha 3, \alpha 4$, and $\alpha 5$ : Represent the values of the variable's coefficients.

$\alpha 0$ - represent the values of the vertical section.

The statistical method adopted is the panel least square regression and T-test used to analyze the data obtained for this analysis. The methodology for the Panel Data consists of combined time and cross-section details. The predictable power of independent variables on the dependent variable is very interesting to examine. Other terminologies used in the above-mentioned kind of data include statistical data and repetitive interventions. A correlation analysis/matrix which was used to check the relationship between the independent variables (liquidity management) and the dependent variable (ROA), as well as testing the existence of multicollinearity among independent variables.

For Panel Data estimation, E-views software has been used. The full sectional and time series data were obtained using Ordinary Least Square (OLS) regression in the same hypotheses. The OLS regression panel has been determined to be appropriate for hypothesis (1), since it was used in this analysis to evaluate the relationship between one dependent and multiple independent variables. A t-test was used for hypothesis two to examine the significant difference in the profitability of deposit money banks before and after the adoption of TSA in Nigeria. 
Furthermore, it is adopted to determine the significant difference between the two means. Also, the t-test is usually applied when the sample size is $<30$. The data used in this study possess elements of both time series and cross sectional. It is best known as panel data (Brooks, 2014). In the analysis of the panel data, the panel regression must be estimated. In the process a "Hausman test" will be carried out to determine what effect applies to the panel data.

\section{RESULTS}

4.1. Hausman Test

The Hausman test was carried out to determine which model best suites the panel regression. The rule of the Hausman test states:

- If the p-value is statistically significant adopt a fixed effect model

- If the p-value is not statistically significant adopt a random effect model.

Table-1. Hausman test.

\begin{tabular}{|c|c|c|c|}
\hline \multicolumn{4}{|c|}{ Correlated Random Effects - Hausman Test } \\
\hline \multicolumn{4}{|c|}{ Equation: Untitled } \\
\hline \multicolumn{4}{|c|}{ Test cross-section random effects } \\
\hline Test Summary & Chi-Sq. Statistic & Chi-Sq. d.f. & Prob. \\
\hline Cross-section random & 10.334518 & 4 & 0.0352 \\
\hline
\end{tabular}

From the analysis in Table 1, the P-value (0.5669) > 5\% significant value, therefore a random effect model shall be used for the regression analysis. For this study a fixed effect model shall be used.

Table-2. Panel OLS

\begin{tabular}{|c|c|c|c|c|}
\hline \multicolumn{5}{|c|}{ Dependent Variable: ROA } \\
\hline \multicolumn{5}{|c|}{ Method: Panel Least Squares } \\
\hline Variable & Coefficient & Std. Error & t-Statistic & Prob. \\
\hline LEV & -9.927049 & 4.379274 & -2.266825 & 0.0249 \\
\hline LDR & -0.028774 & 0.022100 & -1.301996 & 0.1950 \\
\hline $\mathrm{CR}$ & 0.003107 & 0.000696 & 4.464901 & 0.0000 \\
\hline EPS & 0.011126 & 0.000907 & 12.26144 & 0.0000 \\
\hline $\mathrm{C}$ & 1.359021 & 0.364617 & 3.727261 & 0.0003 \\
\hline \multicolumn{5}{|l|}{ Effects Specification } \\
\hline \multicolumn{5}{|c|}{ Cross-section fixed (dummy variables) } \\
\hline R-squared & 0.736026 & \multicolumn{2}{|c|}{ Mean dependent var } & 1.365612 \\
\hline Adjusted R-squared & 0.703482 & \multicolumn{2}{|c|}{ S.D. dependent var } & 3.598116 \\
\hline S.E. of regression & 1.959300 & \multicolumn{2}{|c|}{ Akaike info criterion } & 4.291016 \\
\hline Sum squared resid & 560.4731 & \multicolumn{2}{|c|}{ Schwarz criterion } & 4.648670 \\
\hline Log likelihood & -335.0088 & \multicolumn{2}{|c|}{ Hannan-Quinn criter. } & 4.436200 \\
\hline F-statistic & 22.61586 & \multicolumn{2}{|c|}{ Durbin-Watson stat } & 2.074481 \\
\hline Prob.(F-statistic) & \multicolumn{4}{|l|}{0.000000} \\
\hline
\end{tabular}

\subsection{Interpretation of Panel OLS}

This study is focused on the liquidity management and financial performance of the DMBs of Nigeria. Its liquidity is measured by the accounting liquidity ratios (LEV, CR) also with the loan to deposit ratio (LDR) and the financial performance is measured by the ROA of the bank, its control variables are the bank's size measured by total assets and their EPS. From the Table 2 above, the adjusted r-squared which is denoted by 0.7034 indicates that $70.34 \%$ change in the dependent variable (ROA) as a result of the change in the independent variables (CR, LDR, LEV) whereas the remaining $29.66 \%$ is affected by other factors not captured in the model. From the panel OLS, we can see that the cash ratio $(\mathrm{CR})$ is positively significant and the loan to deposit ratio (LDR) and leverage are both negatively significant also the F-statistics is 22.61586. The Durbin-Watson stat value is 2.0 which indicate 
that there is no autocorrelation in the sample. The EPS is used as the control variable which shows a positive significant effect on the Panel OLS, overall this panel OLS shows that liquidity management has a positively significant effect on the profitability of the DMBs of Nigeria.

Table-3. Paired samples statistics.

\begin{tabular}{c|c|c|c|c|c}
\hline \multicolumn{2}{c|}{} & Mean & N & Std. Deviation & Std. Error Mean \\
\hline \multirow{2}{*}{ Pair 1 } & PRE-TSA & 1.8430 & 30 & 2.29790 & 0.41954 \\
\cline { 2 - 6 } & POST-TSA & 1.6714 & 30 & 1.47753 & 0.26976 \\
\hline
\end{tabular}

The above Table 3 shows the mean and standard deviation of the two periods (pre and post TSA). It shows that the liquidity was significantly higher in the pre-TSA period than the post-TSA period. This indicates that the DMBs were more liquid in the pre-TSA period than the post-TSA period.

Table-4. Paired samples correlations.

\begin{tabular}{c|c|c|c|c}
\hline \multicolumn{6}{|c|}{} & N & Correlation & Sig. \\
\hline Pair 1 & PRE-TSA \& POST-TSA & 30 & 0.578 & 0.001 \\
\hline
\end{tabular}

Table-5. Paired samples test.

\begin{tabular}{|c|c|c|c|c|c|c|c|c|c|}
\hline & & \multicolumn{5}{|c|}{ Paired Differences } & \multirow[t]{3}{*}{$\mathbf{t}$} & \multirow[t]{3}{*}{ Df } & \multirow{3}{*}{$\begin{array}{l}\text { Sig. } \\
\text { (2-tailed) }\end{array}$} \\
\hline & & \multirow[t]{2}{*}{ Mean } & \multirow[t]{2}{*}{$\begin{array}{l}\text { Std. } \\
\text { Deviation }\end{array}$} & \multirow[t]{2}{*}{$\begin{array}{l}\text { Std. Error } \\
\text { Mean }\end{array}$} & \multicolumn{2}{|c|}{$\begin{array}{l}95 \% \text { Confidence Interval } \\
\text { of the Difference }\end{array}$} & & & \\
\hline & & & & & Lower & Upper & & & \\
\hline $\begin{array}{l}\text { Pair } \\
1\end{array}$ & $\begin{array}{l}\text { PRE-TSA - } \\
\text { POST-TSA }\end{array}$ & 0.17159 & 1.88137 & 0.34349 & -0.53093 & 0.87410 & 0.500 & 29 & 0.621 \\
\hline
\end{tabular}

The T-test was carried out using the ROAs from the 2013-2014 and 2016-2017 as the pre and post TSA years respectively making a total sample size of 30 observations which is a condition of carrying out a t-test. The Test was carried out at a significant level of $5 \%$. The results from Table 4 and 5 indicate that there is a significant difference between the ROAs pre and post TSA.

\section{DISCUSSION OF FINDINGS}

The results suggest that liquidity of the DMBs of Nigeria is a significant factor which impacts immensely to the profitability of the banks. It means that there is a significant relationship between liquidity management and the financial performance of the DMBs of Nigeria. The findings from this study are in line with other studies such as Edem (2017); Ahmad (2016); Duruechi et al. (2016); Alshatti (2015) and many others. The study can also draw the conclusion that the TSA policy has significantly impacted on the liquidity of the DMBs of Nigeria, meaning the implementation of the treasury single account have negatively affected the liquidity of the DMBs of Nigeria. This negative effect of TSA policy on the liquidity of DMBs in Nigeria is also in line with the works of Andornimye (2017); Zayol et al. (2017). A functional relationship can be seen from the above, as the TSA negatively affected the liquidity of the DMBs and the liquidity is a key factor of the bank's profitability, therefore as a function of a function the TSA influenced the profitability of the DMBs to a degree, this means the negative relationship with TSA is the reason for the drop in the ROA of the banks after 2014.

\section{CONCLUSION AND RECOMMENDATIONS}

This study sought to discover the effect of liquidity management on performance of DMBs in Nigeria. Secondary data was obtained from 15 DMBs in Nigeria for a period of 11 years (2007-2017). The findings depicted 
a significant effect between liquidity and performance, and also liquidity was significantly higher in the pre-TSA period than the post-TSA period.

This study therefore recommends following measures should be taken to aid the banks in their liquidity aspect of their firm and help them adapt to the implementation of the TSA policy, these measures includes the following: DMBs in Nigeria should employ a good liquidity management system in order to improve their performance.

In relation to the TSA policy, the DMBs should reorganize its internal financial system to adapt to the change which the new policy brings and also to ensure that the new system is flexible enough to accommodate any future change in public or private policies, also due to the TSA policy being relatively new to Nigeria this study recommends further research on this topic.

Funding: This study received no specific financial support.

Competing Interests: The authors declare that they have no competing interests.

Acknowledgement: All authors contributed equally to the conception and design of the study.

\section{REFERENCES}

Aburime, T. U. (2008). Determinants of banks profitability: Macroeconomic evidence from Nigeria. Social Science Research Network, Deakin University.

Agbada, A. O., \& Osuji, C. (2013). The efficacy of liquidity management and banking performance in Nigeria. International Review of Management and Business Research, 2(1), 223-233.

Ahmad, B. R. (2016). A study of relationship between liquidity and profitability of standard chartered bank Pakistan: Analysis of financial statement approach. Double Blind Peer Reviewed International Research Journal, 16(1), 77-82.

Akter, A., \& Mahmud, K. (2014). Liquidity-profitability relationship in Bangladesh banking industry. International Journal of Empirical Finance, 2(4), 143-151.

Alshatti, A. S. (2015). The effect of the liquidity management on profitability in the Jordanian commercial banks. International Journal of Business and Management, 1O(1), 62. Available at: https://doi.org/10.5539/ijbm.v 10n 1 p62.

Amengor, E. C. (2010). Importance of liquidity and capital adequacy to commercial banks. Paper presented at the Induction Ceremony of ACCE, UCC Campus.

Andornimye, L. (2017). Impact of treasury single account (TSA) implementation on bank liquidity in Nigeria. Scholars Journal of Economics, Business and Management, 4(4), 260-264.

Aurangzeb, K. (2012). Contributions of banking sector in economic growth: A case of Pakistan. Economics and Finance Revierw, 2(6), 45-54.

Bassey, A., Tobi, E., Bassey, I., \& EKwere, R. (2016). Liquidity management and performance of banks in Nigeria (2000 - 2010). International Journal of Academic Research in Accounting, Finance and Management Sciences, 6(1), 41-48.

Berle, A. A., \& Means, G. C. (1932). The modern corporation and private property. New York: MacMillan.

Biety, M. (1998). Operational guide line for the development and early credit union operations. Madison, Wis: World Council of Credit Unions, Inc.

Brooks, C. (2014). Introductory econometrics in finance (3rd ed.). New York: Cambridge University Press.

Davronov, S. (2016). Liquidity management in commercial banks of Uzbekistan. Asian Journal of Management Sciences and Education, 5(2), 19-27.

Duruechi, A. H., Ojiegbe, J. N., \& Otiwu, K. C. (2016). Liquidity management measures and bank performance in Nigeria: An empirical analysis. European Journal of Business and Management, 8(17), 24-35.

Edem, D. B. (2017). Liquidity management and performance of deposit money banks in Nigeria (1986-2011): An investigation. International Journal of Economics, Finance and Management Sciences, 5(3), 146-161. Available at: https://doi.org/10.11648/j.ijefm.20170503.13.

Egbide, B., Uwuigbe, O., \& Uwuigbe, U. (2013). Liquidity management and profitability of manufacturing companies in Nigeria. Journal of Business and Management (IOSR-JBM), 9(1), 13-21. Available at: https://doi.org/10.9790/487x-0911321. 
Eugene, O. (2017). The effect of liquidity management on the profitability of deposit taking financial institutions in Kenya. A Dissertation Submitted in Partial Fulfillment of the Requirements for the Award of Master of Science (Finance and Investment) Degree, School of Business, Kca University.

Ibe, S. O. (2013). The impact of liquidity management on the profitability of banks in Nigeria. Journal of Finance and Bank Management, 1(1), 37-48.

Ighosewe, E. F., \& Ofor, N. T. (2017). Effect of treasury single account (TSA) on banks performance in Nigeria, an exploratory study, sahel analyst. Journal of Management Sciences, 15, 32-49.

Jensen, M., \& Meckling, W. H. (1979). Rights and production functions: An application to labor-managed firms and codetermination. The Journal of Business, 52(4), 469-506. Available at: https://doi.org/10.1086/296060.

Molefe, B., \& Muzindutsi, P. (2016). Effect of capital and liquidity management on profitability of major South African banks. Paper presented at the Proceedings of the 28th Annual Conference of the Southern African Institute of Management Scientists, Pretoria.

Ndubuaku, V. C., Ohaegbu, O. K., \& Nina, N. M. (2017). Impact of treasury single account on the performance of the banking sector in Nigeria. IOSR Journal of Economics and Finance, 8(4), 8-15. Available at: https://doi.org/10.9790/59330804010815.

Obinna, C. (2015). Banks face liquidity strain as FG fully enforces treasury single account. Thisday, Monday, 11 August, 52.

Ogundipe, S. E., Idowu, A., \& Ogundipe, L. O. (2012). Working capital management, firms' performance and market valuation in Nigeria. World Academy of Science, Engineering and Technology, 61(1), 1196-1200.

Okere, W., Isiaka, M. A., \& Ogunlowore, A. J. (2018). Risk management and financial performance of deposit money banks in Nigeria. European Journal of Business, Economics and Accountancy, 6(2), 30-42.

Olarewaju, O. M., \& Adeyemi, O. K. (2015). Causal relationship between liquidity and profitability of Nigerian deposit money banks. International Journal of Academic Research in Accounting, Finance and Management Sciences, 5(2), 165-171. Available at: https://doi.org/10.6007/ijarafms/v5-i2/1692.

Oyedele, T. (2015). Treasury single account and taxation. PWC Nigeria. Retrieved from: http://pwcnigeriatypepad.com/files/tsa-andltax.

Sewa, W. (2015). In Obina C. (2015). Banks face liquidity strain as federal government fully Enforces treasury single account, Thisday Live. 11 th Aug.

Zayol, P., Iorlaha, T., \& Nege, J. (2017). Effect of treasury single account on the liquidity of deposit money banks in Nigeria. Journal of Economics and Finance, 8(4), 55-60.

Views and opinions expressed in this article are the views and opinions of the author(s), Journal of Asian Business Strategy shall not be responsible or answerable for any loss, damage or liability etc. caused in relation to/arising out of the use of the content. 